\title{
Economics
}

2019; 8(4): 134-141

http://www.sciencepublishinggroup.com/j/eco

doi: $10.11648 /$ j.eco.20190804.12

ISSN: 2376-659X (Print); ISSN: 2376-6603 (Online)

\section{Role and Determinants of Saving and Credit Cooperative on Financial Intermediation in Hadiya Zone, Southern Ethiopia}

\author{
Abel Wudenah Abamagal ${ }^{1}$, Philipos Wudineh Abamagal ${ }^{2}$ \\ ${ }^{1}$ Department of Economics, College of Business and Economics, Woliata Sodo University, Woliata Sodo, Ethiopia \\ ${ }^{2}$ Marketing and Cooperative Department, Hosanna Town Administrative, Hadiya Zone, Ethiopia
}

Email address:

wudabel2007@gmail.com (A. W. Abamagal)

To cite this article:

Abel Wudenah Abamagal, Philipos Wudineh Abamagal. Role and Determinants of Saving and Credit Cooperative on Financial Intermediation in Hadiya Zone, Southern Ethiopia. Economics. Vol. 8, No. 4, 2019, pp. 134-141. doi: 10.11648/j.eco.20190804.12

Received: July 4, 2019; Accepted: August 5, 2019; Published: November 14, 2019

\begin{abstract}
This study aimed to assess role and determinants of saving and credit cooperative on financial intermediation in Hadiya Zone, in case of Lemo woreda and Hosanna town administrative. The main target of this study was in order to assess role of saving and credit cooperatives for their members in financial intermediation and to examine main determinants of saving and credit cooperatives activities on financial intermediation. Both primary and secondary data were used, the primary data was collected through structured questionnaire based on 156 members' respondents of cooperative and 156 respondents from saving and credit cooperative total 312 respondents from both Lemo Woreda and Hosanna town. Secondary data were collected from all saving and credit cooperatives and other relevant organizations those from Lemo woreda and Hadiya zone cooperative and marketing organization. Data analysis is carried out with the help of various descriptive and econometric techniques that logit model. Descriptive method was employed to assess role of saving and credit cooperatives in financial intermediation and logit model were employed to identify determinants that influence their financial intermediation role on members. Analysis result implies that saving and credit cooperatives have significant role on their member's resource mobilization or to enhance saving culture, creating credit provision on moderate financial intermediation. In case of factors that determine financial intermediation of cooperatives member's participation on cooperatives, different training especially for cooperative administrative, sufficient supervision and audit system, and political disturbance or intervention on their objectives significantly influence financial intermediation performance.
\end{abstract}

Keywords: Cooperative, Financial Intermediation, Saving, Credit, Logit

\section{Introduction}

Savings and credit cooperative societies (SACCOs) in the world can be traced based on two origin of modern cooperation. The first modern co-operation emerged in certain working class environments in European industrial cities in 1840 particularly, in Great Britannia and France. The pioneers invented model of consumer and labor cooperatives that defend and promote the interest of working class in the face of social disasters endangered by the industrial revolution [1].

Tradition cooperation involved community members voluntarily pooling financial resources through "Iqub", which was an association of people having the common objectives of mobilizing resources, especially finance, and distributing it to members on rotating basis. There were also initiatives for labor resource mobilization that were to overcome seasonal labor peaks, known as "Jigie", "Wonfel", Idir, among others. Modern cooperatives in Ethiopia were started at the time of Emperor Haile Sellassie in 1961 by Decree No $44 / 1961$ and later on a proclamation were enacted on 1966, with in short comings, this legal ground gave inputs for cooperative development in the country (Federal Cooperatives Agency, 2012).

During regime (1974-1991), different types of cooperative societies (Agricultural Cooperatives, Housing Cooperatives, Saving and Credit Cooperatives and Mining Cooperatives) were organized, promoted, regulated and inspected by 
different ministries and institutions [10]. Through in this time, cooperatives were mainly organized to transform rural economy to the socialist style rather than benefiting their members. In this process internationally accepted cooperatives principle was violated which consequently to the disbanding of cooperatives and devastation of their properties during the transition period [4]. Establishment of saving and credit cooperative societies in Ethiopia started in the mid-1960s, from 1964-1973, there were 28 saving and credit cooperative societies and these societies formed their own national apex body known as Ethiopian Thrift and Cooperative Societies Limited [10]. SACCO's have been growing fast since 1979, however; the rate of growth is slower than other types of cooperatives in Ethiopia. The number of SACCOs in Ethiopia was 3,491 currently SACCOs [5].

The basic objective of a cooperatives is not "to maximize profits" as a capitalist company nor to act initially like "actor of social change" as in the non-profit-making association but "to maximize the benefit which the member users can obtain from their commercial transitions with the cooperatives [2]. According to the European Commission as many as three Million people still lack access to formal financial service such as bank account, credit, insurance, a safe place to keep saving and a secure and efficient means to receive social benefit payments through a registered financial institution. Low income countries face especially threatening challenges that usually the weaker sections of the societies are completely ignored by the formal financial institution in the race of making pieces of profits or the complexities involved in providing finance to the weaker section $[13,15]$. However, currently some formal financial institution contributing good role and reduce exclusion of low income households from formal financial institution by playing as financial intermediation.

Financial intermediation can be pronounced as the process performed by financial intermediaries of collecting savings and deposits from savers and depositors' and lending out the same to borrowers. Financial intermediation is the root institution in the savings-investment process [7]. The financial intermediation a financial institution will engage in financial transactions on behalf of lenders and savers in a specialized market i.e. a financial market [11]. The institution will therefore expose itself to the risk of losing money on behalf of the lenders/saver by lending the same to borrowers; thus the role of financial intermediaries therefore is to channel funds from lenders to borrowers by intermediating between them.

SACCOs are established under the Co-operative Societies act and are an important form of financial intermediary, which play a vital role in provision of financial services to their member [6]. The societies accept monthly payment/savings for shares from which members may borrow an amount equivalent to two or three times their own savings if they can get other members to guarantee them. SACCOs are currently organized as workplace or agricultural based savings or an economic activity based association like working together in the same company or institution, save regularly thus building enough deposits for lending within the group.

Saving and credit cooperatives are play a critical role in financial intermediation, it facilities and make easier for poor clients to turn small amount of money in to "useful Lump sums", enabling them to smooth consumption and mitigate the effect of economic shocks [12]. Further Sacco provides convenient and safe way to store funds and creates standardized forms of securities and also facilitates easy exchange of funds [14].

Some evidence shows that employers are looking for opportunities to save their income in case of emergencies or to be able to undertake larger investments in the future [3]. Evidence shows that people are looking for opportunities to save their surplus income in case of emergencies or to be able to undertake larger investments in the future without having to take a loan [3]. There is a high potential to mobilize savings among low income people in low income countries. However, people used to mostly rely on informal often insecure ways of saving, such as saving circles or hiding money under the mattress [15]. Providing people with secure opportunities to save can minimize the losses, which arise from the insecure ways of savings, and therefore empower them financially.

The channeling of funds between the two groups of lenders and borrowers can only happen accurately in the presence of particular participants and via main routes such as financial intermediaries or through the use of organized financial markets. Financial intermediaries can substantially reduce transaction costs that can be defined as the time and money spent in performing financial transactions for instance the exchange of assets, goods or services [9]. The most important economic function of financial intermediations is to enhance mobilization of saving and providing loan to its members. The mobilization of saving must be accompanied by providing a safe place for both members and nonmember's savers. The provision of credit has increasingly been regarded as an important tool for raising the income of third world populations, mainly by mobilizing resources to more productive uses.

The major problem of cooperatives in Africa are absence of experienced managers, uneconomic base level units, lacks of supporting infrastructure like extension, poor member participation, insufficient supervision of cooperatives and too much political disturbance. Perhaps the most important factor that determines the success of financial cooperatives is the quality of internal governance; the governance structures of SACCO's have typically three ties, the general assembly of the members, a board of directors elected by the general assembly, and a management team appointed by the board [16]. In most case, also shortage of financial source for loan provision, inadequate entrepreneur skill, lack of awareness on service and weak financial management system challenge primary and union Sacco's performance [8].

The generation of self-employment in non-formal activities requires investment in working capital. However, at low levels of income, the accumulation of such capital may be difficult. Under such circumstances, loan, by increasing family income, 
can help the poor to accumulate their own capital and invest in employment-generating activities. The other essential function of a SACCO is investment, which allows members to form business by placing their capital at risk sharing and to receive the return (profit) on the investment. Therefore, this research aims to investigate the role and determinants of SACCOs on financial intermediation for members of saving and credit cooperative societies.

\section{Methodology}

\subsection{Data Type and Source}

For this study both primary and secondary data were employed to answer each and specify objective that stated on paper. The primary data were collected from Lemo Woreda and Hosanna administrative from each saving and credit cooperative members and administrative. This primary data was collected from the sampled respondents of both cooperative members and admin on different characteristic such as demographic and socio-economic characteristics of households. Secondary data were collected from all saving and credit cooperatives and other relevant organizations those from Lemo woreda and Hadiya zone cooperative and marketing organization.

\subsection{Method of Data Collection}

To collect primary data from both cooperative members and administrative about different characteristic such as demographic and socio-economic characteristics of households investigators were employed structured questionnaires. The questionnaires were containing as pilot both closed and open ended questions. Close ended question is formulated because they are easy to administrate and easier to analysis, open ended question was used by cause that permit a greater depth of response and expression the questionnaires administrated to garner data from those categories with numerous respondents. That questionnaire was first prepared in English language, and then it translated in to Amharic and Hadiyegna language to facilitate the interview process. The data was collected from two clusters of the populations made up of the management's staff and members of the SACCO's by administrating two different questionnaires to each group.

$$
\operatorname{Logit}(Y)=Y=\ln [p /(1-p)]=\beta 0+\beta 1 X 1+\beta 2 X 2+\beta 3 X 3+\beta 4 X 4 \ldots \ldots \beta n X n
$$

Whereby; $\mathrm{Y}$ as a binary response variable

Where $\mathrm{P}$ is the probability of the event of financial intermediation, $\alpha$ is the $\mathrm{Y}$ intercepts, $\beta_{\mathrm{n}}$ are regression coefficients, and $\mathrm{X}_{1}, \mathrm{X}_{2}, \mathrm{X}_{3} \ldots . . \mathrm{X}_{\mathrm{n}}$ are a set of predictors which indicate hypothesized determinant variables in the model.

$$
\mathrm{Y}=\beta 0+\beta 1 \mathrm{X} 1+\beta 2 \mathrm{X} 2+\cdots \ldots+\beta 9 \mathrm{X} 9
$$

$\mathrm{Y}=$ financial intermediation of SACCO

$\mathrm{X}_{1}=$ performance of saving and credit cooperatives

$\mathrm{X}_{2}=$ having managerial experience of mangers of saving

\subsection{Sampling Methods and Sample Size}

The researcher was used census survey sampling method to determine sample respondent from saving and credit cooperatives administrators that it take whole 156 respondents. According to the data that obtained from Lemo Woreda and Hosanna Town administration cooperative (2018) total number of members in saving and credit cooperative was 1560 . So, to take sample respondents from members of saving and credit cooperatives investigator takes ideal $10 \%$ from the total number of members in saving and credit cooperative in both Lemo Woreda and Hosanna Town. Therefore, 156 sample size (n) for members were taken for this study because this fulfill minimum ideal sample size household for reliable results. Hence for this study in order to collected reliable data were 156 from saving and credit cooperative administrative and 156 from cooperative members on both Lemo Woreda and Hosanna town administrative. So, for this investigation researcher were used total 312 sample sizes.

\subsection{Methods of Data Analysis}

To analysis collected data from those respondent based on specified objectives researchers were employed both descriptive statistics and econometric model. i.e descriptive like percentage, mean and standard deviation were employed and from econometric model binary logestic regression were employed. Logit model was employed to identify the main determinants of saving and credit cooperatives on their performance especially in financial intermediation. Further the data was analyzed using stat software version 13 for both descriptive statistics and econometric model.

\section{Model Specification}

i. Binary logistic regression model

A logistic regression was used to identify the factors determine performance of saving and credit institution in financial intermediation. The model was used as it were designated to one or two possible outcomes (a binary response). So in this model dependent variable include two outcome that $\mathrm{Y}=1$ when saving and credit cooperative has play as financial intermediary and $\mathrm{Y}=0$ it has not play as financial intermediary for their members. The binary Logistic regression model is expressed as follows: and credit cooperatives

$\mathrm{X}_{3}=$ human resource constraints of saving and credit cooperatives

$\mathrm{X}_{4}=$ financial constraint of saving and credit cooperatives

$\mathrm{X}_{5}=$ members participation on cooperatives

$\mathrm{X}_{6}=$ training for SACCO administrative

$\mathrm{X}_{7}=$ sufficient supervision from other institution

$\mathrm{X}_{8}=$ sufficient on time auditing

$\mathrm{X}_{9}=$ political disturbance

Explanatory variables

The explanatory variables in the logit analysis include 
the demographic and socio-economic characteristics that hypothesized as determinants that influence performance of financial intermediary role of saving and credit cooperative those may be positively or negatively.

\section{Results and Discussions}

\subsection{Demographic Information of the Respondents}

\subsubsection{Gender of the Respondents}

With development and modernization, gender equality has turned to be an important consideration in almost all domains of life including in organization. Logic that many psychologists argue that male and female perceive or interpret things differently, even though they may be exposed to the same kind of environment. According to the finding of this study majority of the SACCOs administration 92 (59\%) were male with $64(41 \%)$ being female whereas $89(57 \%)$ of the respondent of SACCOs members were male while 62 $(40 \%)$ were female $5(3 \%)$ are non-responsive.

Table 1. Respondents Gender.

\begin{tabular}{lllll}
\hline \multirow{2}{*}{ Descriptions } & SACCOs Administration & & SACCOs Members \\
\cline { 2 - 5 } & Frequency & Percentage & Frequency \\
\hline Non responsive & - & - & 5 & Percentage \\
Male & 92 & 59 & 89 & 3 \\
Female & 64 & 41 & 62 & 57 \\
Total & 156 & 100 & 40 & 156 \\
\hline
\end{tabular}

Source: Own field data, 2018.

\subsubsection{Educational Back Grounds of Respondents}

The most important considerable factor that affects conceptualization, understanding for decision making and in implementing ideas is Education, for the reason the formal education was therefore, an important aspects. As shown on below table 2, most of respondents that means 94 (59\%) of the SACCs administrations had certificate and diploma, 60 (39\%) of respondent were bachelor degrees while $2(1.2 \%)$ were master's degree holders.

Table 2. SACCOs administrative respondent education level.

\begin{tabular}{lll}
\hline Education level & Frequency & Percentage \\
\hline Certificate and Diploma & 94 & 59 \\
Bachelor degree & 60 & 39 \\
Masters & 2 & 1.2 \\
\hline
\end{tabular}

Source: Own field data, 2018

On the other hand, as shown in below table 3 , that majority of respondent from members of saving and credit cooperative were certificate and diploma holders that means $79(50.64 \%)$ of the SACCOs member, 72 (46.15\%) were bachelor's degree holders and 5 (3\%) were master's degree holders.
Table 3. Sacco's member's respondent education status.

\begin{tabular}{lll}
\hline Education level & Frequency & Percentage \\
\hline Certificate Diploma & 79 & $50.64 \%$ \\
Bachelor degree & 72 & $46.15 \%$ \\
Masters & 5 & $3.2 \%$ \\
\hline
\end{tabular}

Source: Own field data, 2018

\subsubsection{Duration of Time as SACCO's Members and Administrations}

It is perceived that experience, that mean continuing long time as member on saving and credit cooperative is a key component in the organizational stability and performance, from the finding it emerged that the majority of the respondent of SACCOs administrations 39 (25\%) had the members of SACCO's for less than five years with 67 (43\%), 34 (22\%) and $16(10 \%)$ had been members for 5-10, 11-15 years and 15 years and above respectively. On the other had a significant majority 30 (19\%) of the respondent of SACCOs members had been in their respective SACCOs for less than 5 years with 84 (54\%) have been members for a period of between 5-10 years, $25(17 \%)$ have been $11-15$ years, whereas $11(7 \%)$ had been in the organizations for more than 15 years.

Table 4. Duration of time that individual members and SACCOs administrations stay in saving and credit cooperative as member.

\begin{tabular}{lll}
\hline Duration of time on SACCOs for SACCOs administrations & Frequency & Percentage \\
\hline Less than 5 year & 39 & $25 \%$ \\
Between 5-10 year & 67 & $43 \%$ \\
Between 10-15 year & 34 & $22 \%$ \\
Above 15 year & 16 & $10 \%$ \\
Total & 156 & $100 \%$ \\
Duration of time on SACCOs for members & Frequency & Percentage \\
Less than 5 year & 30 & $19 \%$ \\
Between 5-10 year & 84 & $54 \%$ \\
Between 10-15 year & 26 & $17 \%$ \\
Above 15 year & 11 & $7 \%$ \\
Total & 156 & $100 \%$ \\
\hline
\end{tabular}

Source: Own field data, 2018 


\subsection{SACCO's Contribution on Mobilizing Savings and Enhances a Saving Culture}

As per below table respondent response result that most SACCO's administrative respondents indicate saving and credit institution have high contribution on mobilizing saving and in improving saving culture. That mean as shown in table 5 below that majority of respondent $33(85.1 \%)$ were agree on SACCO's role in mobilizing savings and enhancing saving culture and only $18(11 \%)$ were disagreement on SACCO's role in mobilizing savings and enhancing saving culture. This implies that saving and credit cooperatives significant contribution on its member in mobilizing and improving saving culture.

Table 5. Whether SACCO's play a role in mobilizing savings and enhancing saving culture.

\begin{tabular}{|c|c|c|}
\hline & Frequency & Percent \\
\hline Non Responsive & 5 & 3.2 \\
\hline Strongly disagree & 10 & 6.0 \\
\hline Disagree & 8 & 5.7 \\
\hline Agree & 82 & 52.5 \\
\hline Strongly agree & 51 & 32.6 \\
\hline Total & 156 & 100.0 \\
\hline
\end{tabular}

Source: Own field data, 2018

\subsection{Role of SACCO's in Loan Provision for Their Members}

As shown in table below on role of SACCO's in the provision of loans to its esteemed customers, the investigators sought to get both respondent administrators and members whether they perceived SACCO's to have a role in loan provision to its customers. Based on the findings data result majority that $136(87 \%)$ of the respondent
SACCO members were in acknowledgement that SACCO's play a role in loan provision to its members against a mere 20 $(13 \%)$ who were in disagreement on the loan provision service cooperative. On the other hand majority 131 (84\%) of the respondent SACCO administrator were in agreement that SACCO's have a role in loan provision to its members compared to $25(16 \%)$ who were in disagreement.

Table 6. Role of SACCO's in loan provision for their Members.

\begin{tabular}{llll}
\hline Respondent categories & Response on role of SACCO & Frequency & Percentage \\
\hline \multirow{2}{*}{ SACCO administrator respondents } & Agree on SACC role of loan provision & 131 & $84 \%$ \\
& Disagree on SACC role of loan provision & 25 & $16 \%$ \\
Member of SACCO & Agree on SACC role of loan provision & 136 & 20 \\
& Disagree on SACC role of loan provision & 20 & $13 \%$ \\
\hline
\end{tabular}

Source: own field data, 2018

\subsection{Econometric Regression Result}

Before employing regression, data were checked for occurrence of strong multi-collinearity among explanatory variable by using appropriate diagnostic techniques. Based on that, existence of strong multi-collinearity was tested by using contingence coefficient. There was no any explanatory variable dropped from estimated model since no serious problem of multi-collinearity were detected from contingency coefficient results. The decision rule for contingency coefficient states that when its value approaches to $1(>0.75)$ there is a problem of multi-collinearty among variables. The below table reveal that as no correlation value indicate above 0.75 , hence on all variables that included in model no multi-collinearty puzzle. Which show maximum level of correlation among variable is 0.4992 that between performance of SACCO and human resource in SACCO even which is less than 0.75 see below table result.

Table 7. Multi-collinearity among variables that hypothesized in model.

\begin{tabular}{|c|c|c|c|c|c|c|c|c|c|c|}
\hline & prefsa o & mngexp & hresou e & fconstra & mpartic & training & sufsupr & sufaudit & podist $\sim$ b & fintemd \\
\hline prefsacco & 1.0000 & & & & & & & & & \\
\hline mngexp & -0.2538 & 1.0000 & & & & & & & & \\
\hline hresource & 0.4992 & -0.1958 & 1.0000 & & & & & & & \\
\hline fconstra & -0.0249 & -0.0392 & -0.0921 & 1.0000 & & & & & & \\
\hline mpartic & 0.1126 & 0.0106 & 0.1291 & -0.2943 & 1.0000 & & & & & \\
\hline training & 0.1675 & 0.0866 & 0.1554 & -0.1697 & 0.0979 & 1.0000 & & & & \\
\hline sufsupr & 0.2662 & -0.0033 & 0.2731 & -0.0573 & -0.0712 & 0.2199 & 1.0000 & & & \\
\hline podistrib & 0.1549 & 0.2300 & 0.1245 & 0.2600 & 0.2048 & 0.1734 & -0.034 & -0.0725 & 1.0000 & \\
\hline fintemd & 0.3981 & -0.0105 & 0.3299 & -0.2703 & 0.2423 & 0.4435 & 0.2451 & 0.1463 & -0.0143 & 1.0000 \\
\hline
\end{tabular}

Source: Own field data, 2018 
Determinants of Saving and Credit Cooperatives on Financial Intermediation

As specified in the model specification part of study dependent variable a dummy variable indicating whether the saving and credit cooperative has serving as financial intermediation for the members that value of 1 if it have and 0 , otherwise. As shown below table 8, among eight that hypothesized covariates four variables are significantly determine or affect the financial intermediation of saving and credit cooperatives on their members.

Table 8. Logit regression show factors that influence SACCO on financial intermedation.

\begin{tabular}{|c|c|c|c|c|c|}
\hline Fintemd & Odds Ratio & Std. Err. & Z-value & \begin{tabular}{l|l|}
$\mathbf{P}>$ & $\mathbf{z}$ \\
\end{tabular} & Marginal effect \\
\hline cons & 0007045 & 0001854 & -4.08 & $0.000 * * *$ & \\
\hline prefsacco & 4.922179 & 2.934681 & 1.41 & 0.219 & 4088019 \\
\hline mngexp & 8211121 & 940099 & 2.51 & $0.066^{* *}$ & 1563731 \\
\hline hresource & 1.063222 & 1.083011 & 1.39 & 0.545 & 1700128 \\
\hline fconstra & 1.389094 & 3743384 & -0.61 & 0.545 & -.0722874 \\
\hline mpartic & 1.890728 & 2.369161 & 2.73 & $0.006 * * *$ & 3457939 \\
\hline training & 4923579 & 9.704791 & 4.34 & $0.001 * * *$ & 158462 \\
\hline sufaudit & 7055217 & 1.09458 & 2.19 & $0.036^{* *}$ & 083072 \\
\hline podistrib & 2126475 & 1767899 & -2.07 & $0.039 * *$ & -.319167 \\
\hline Number of obs- 156 & & & Prob $>$ ch & & \\
\hline LR chi $^{2}$ (13) -76.54 & & & Pseudo R & & \\
\hline
\end{tabular}

Source: own survey data, 2018. Note: $* * * \mathrm{p}<0.01, * * \mathrm{p}<0.05$ and $*<0.1$ significance level of explanatory variables.

As revealed in above table significant variable for detail managerial experience of saving and credit cooperative manager was positively related and the coefficient is different from zero at $10 \%$ significance level with finance intermediation function. Holding all other variable in model constant as one year managerial experience raise the performance saving and credit cooperative on financial intermediation increase at about 0.156 or 15.6 percent. This implies saving and credit cooperative with good experience manager have high probability to register high financial intermediation role on its members.

In place of members participation on saving and credit cooperatives have great influence on financial intermediation, that members participation was positively related and its coefficient is different from zero at $1 \%$ significance level. Holding all other variables that hypothesized in model constant, as member participation increase saving and credit cooperative performance rise on financial intermediation at about 0.34 or by $34 \%$. From logit result the third variable that significantly influence financial intermediation of saving and credit cooperatives is having training for credit comment, chairman and other concerning committee have positive relation with financial intermediation and its coefficient is different from zero at $1 \%$ significance level. That means when remaining variables that included in model constant increase training for concerning body in cooperative increase its financial intermediation at 0.158 o by $15.8 \%$. Similarly both supervision and yearly auditing have positive and their coefficients are different from zero at $5 \%$ significance level. i.e supervision and auditing when others variable that included constant having good supervision and auditing raise performance of saving and credit cooperative on financial intermediation role by $0.021(2.1 \%)$ and $0.083(8.3 \%)$ respectively.

To end with significant determinants of financial intermediation performance of saving and credit cooperative is policy disturbance (political intervention) which is negatively related and its coefficient greater than zero at $5 \%$ significance level. When holding all other variables that hypothesized in model constant in which a discrete increase in political disturbance or intervention on saving and credit cooperative decrease financial intermediation of at 0.32 or by $32 \%$. Remain variables out of those listed above as significant determinants of financial intermediation of saving and credit cooperatives were insignificant.

\section{Conclusion}

The chapter looks at the conclusions drawn from the research, comparison to what other scholars say as noted under literature review and what recommendations the study has come up with in the role and determinants of savings and credit cooperative societies (SACCO's) in financial intermediation.

The basic role of financial intermediaries is transforming financial assets that are less desirable for a large part of the public into other financial asset, which is preferred more by the public.

Based on the study result majority of the respondent of SACCOs administrations 39 (25\%) had the members of SACCO's for below 5 years had been members. On the other hand a significant majority $30(19 \%)$ of the respondent of SACCOs members had been in their respective SACCOs for less than 5 years also from respondent 84 (54\%) had experience of membership for a period of between 5-10 years. As per table above analysis part that from total respondent $67(43 \%)$ indicate the time that stay on saving and credit cooperative between 5-10 year. Likewise, from total respondent of members of saving and credit cooperative have $26(17 \%)$ experience for $10-15$ year and $34(22 \%)$ of SACCO's administrative of respondent indicate between 1015 year in cooperative as members. The remains respondents 
report that they have long time experience on SACCO's that means $16(10 \%), 11(7 \%)$ from SACCO's administrative and members respectively. This implies that most of members have more than five year experience on saving and credit cooperative.

Concerning the contribution of saving and credit cooperative definitely role of SACCO's as financial intermediation, most of respondent indicate cooperative play important role on member.

Based on this study result revealed that majority 133 $(85.1 \%)$ of respondent agree on SACCO's contribution in which it played important role in mobilizing savings that 18 (11\%) who were in disagree on contribution of cooperatives on financial intermediation. Some literature review state that, financial intermediaries provide convenient and safe way to store funds and creates standardized forms of securities which is consistent with our study result [14]. The study sought to distinguish whether SACCO's had a role in loan provision to its members, $86 \%$ of the respondent SACCO members were in acknowledgement that SACCO's played a role in loan provision to its customers with $84 \%$ of the respondent SACCO administrator sharing the same sentiments. This implies that saving and credit cooperative play crucial role on its member by providing loan and creating good opportunities of loan.

Generally, as study result revealed saving and credit cooperative have huge role for their members like on mobilizing saving culture of members, saving and credit cooperative have role by providing loan for members and contribution for their members in fund mobilizing. Which implies that saving and credit cooperatives have good role for their members as financial intermediaries for most economic activates on study area that Lemo district and Hosanna Town.

Based on logit regression result to examine the determinant of saving and credit cooperatives on financial intermediations in study area, regression result reveal that saving and credit cooperative mainly determined by managerial experience of cooperative determine manager at $10 \%$ significance level, active participation member on saving and credit cooperatives also determine performance of saving and credit cooperative at $1 \%$ significance level. Financial intermediations role performance of SACCO also determined by training access that provided for cooperative administrative staff affect at $1 \%$ significance level. Continuous supervision, yearly auditing likewise determine financial intermediations performance of saving and credit cooperative at 5\% significance level. Lastly, political disturbance or interventions on this autonomous institution affect negatively SACCO performance on financial intermediation at similarly 5\% significance level.

\section{Recommendation}

Based on finding of study researchers construct the following recommendation for concerning body:-

Continuously education, good motivation on business skill for SACCO members and additional managerial training and administrators is very essential to go financially well-being in future.

Good approach enters membership relation and standing for communal benefit strengthening is a necessary condition for sustaining the cooperative legacy and to achieve good performance on financial intermediation. Hence, SACCO should work good to increase membership of society by creating awareness about objective, benefit and whole task that cooperative provide and perform.

Sufficient supervision and auditing have significant effect saving and credit cooperative performance on financial intermediation. Therefore concerning stockholders and government should support this institution specifically by supervision and auditing. Continuous training of administrators on the SACCO management policies and how it link up with daily SACCO operations and better service delivery to the members.

Participation of members on cooperative have good role for institutional performance of saving and credit cooperatives governments and other stakeholder should give credit and work hard to rise participation of members. Other main determinants that influence saving and credit cooperative ability for financial intermediation is political intervention hence government should support cooperative by reducing its intervention.

\section{Acknowledgements}

We thank Wolaita Sodo University for support on data collection for this study even if, the funding does not cover publication process. Study participants, data collectors, and supervisors are acknowledged for their cooperation during data collection. Author's Contribution AW was involved in conception, design, analysis, interpretation, report and manuscript writing. PW was involved in the design, analysis, interpretation and report writing. All authors read and approved the final manuscript.

\section{References}

[1] Assenga, E; Mwageni E and Kayunze K, (2013). SACCOS and Women's Poverty Reduction InMorogoro District, Tanzania; volume, 20 No 2.

[2] Birchall, J (2004). Cooperatives and the Millennium Development Goals Geneva, International Labour Office.

[3] CGAP, (2006) Regulation, Supervision, Government and Control in Cooperative.

[4] Dagnew G, (2004) Saving and Credit Co-Operative in Ethiopia Microfinance Development Review. Volume 3 No 2.

[5] Dessalew A. (2014), The Socio-Economic Role of Saving and Credit Cooperatives in Promoting Gender Equality: The Case of Estie Woreda, Ethiopia. European Journal of Business and Management, Vol. 6, No. 1, PP 1-7

[6] Donaldson, T. H. (2009). Credit risk and exposure in securitization and transactions. New York, NJ: St. Martin's Press. 
[7] Gorton, G and Winton, A (2002); Financial intermediation, Working Paper, 8928; National Bureau of Economic Research, 1050 Massachusetts Avenue.

[8] Kifle T. (2012), The Impact of Savings and Credit Cooperatives in Ofla Wereda Tigray Region of Ethiopia. European Journal of Business and Management, Vol 4, No. 3.

[9] Mishkin, F and Eakins, S, (2006). Financial Markets and Institutions, 5th Edition; Columbia University.

[10] Muluneh, A (2012), Financial Inclusion Buttress incomes, assets, reduce vulnerability to shocks, Birritu 2012 No 113.

[11] OECD (Organisation for Economic Co-operation and Development). (2005). OSLO Manual: Guide-lines for Collecting and Interpreting Innovation Data. Paris: OECD.
[12] Rutherford, M. (2001). "Institutional Economics: Then and Now." Journal of Economic Perspectives, 15 (3).

[13] Sharma A, and Kukreja S, (2013). An Analytical Study: Relevance of Financial Inclusion for Developing Nations. International Journal of Engineering and Science.

[14] Sullivan, A. and Sheffrin, M. S (2003). Sustainable Development in the Context of Major Infrastructure Projects in United Kingdom.

[15] Wright, Graham A. N. (2000). Microfinance Systems: Designing Quality Financial Services for the Poor. Zed Books Ltd. London \& New York, and University Press Limited, Dhaka.

[16] World Bank, (2006) Cooperative financial institutions: issues in governance, regulation, and supervision. 